\title{
Konsep diri remaja yang terlibat minuman Keras (Khamar) Di Lingkungan Rampusa Kelurahan Betteng Kecamatan Lembang Kabupaten Pinrang
}

\author{
Hasna \\ Prodi Bimbingan Konseling Islam \\ IAIN PAREPARE
}

\section{PENDAHULUAN}

Indonesia dalam meningkatkan sumber daya manusia di era globalisasi yang semakin canggih, kita perlu mempersiapkan generasi muda penerus bangsa melalui pendidikan formal dan nonformal baik dibidang agama, pendidikan maupun dibidang yang menunjang daya saing bagi bangsa asing. Indonesia yang merupakan mayoritas penganut agama islam yang dimana islam melarang umatnya untuk meminum-minuman keras, tapi masih banyak ditemukan perilaku meyimpang seperti meminum minuman keras baik di pedesaan maupun di perkotaan. Dalam pandangan islam, melakukan perilaku menyimpang ini menadakan bahwa kualitas hidup remaja mengalami penurunan akhlak, nilai dan norma. Yang mengakibatkan dengan mudahnya masyarakat khususnya remaja melakukan perilaku menyimpang. Oleh karena itu perlunya menanamkan nilai-nilai kehidupan dalam diri remaja sejak dini.

Sulawesi Selatan adalah salah satu daerah di Indonesia yang subur yang terdiri banyak suku, agama dan budaya tradisi dan kebiasaan. kebiasaan yang dilakukan bisa berupa kebiasaan baik maupun kebiasan buruk. Salah satu kebiasaan yang sering dilakukan masyarakat khususnya di wilayah pedesaan adalah minum-minuman keras atau yang dikenal dengan istilah tuak/ballo, bukannya jadi kebiasaan akan tetapi sudah dianggap sebagai pelengkap hidup, Minuman keras/tuak adalah minuman khas Sulawesi Selatan yang sangat di gemari oleh masyarakat. salah satu kabupaten yang ada di Sulawesi Selatan yang sebagian masyarakatnya dikenal sebagai penghasil sekaligus pengonsumsi tuak yaitu di Kabupaten Pinrang, tepatnya di Lingkungan Rampusa Kelurahan Betteng Kecamatan Lembang Kabupaten Pinrang. Dimana 
masyarakat di wilaya tersebut menjadikan ballo sebagai sala satu penghasil utama. Yang dimana pada mulanya minuman keras ini hanya dikalangan dewasa saja akan tetapi anak remaja sekarang sudah mulai ikut serta dalam hal minuman ini.

Masa remaja sering dikenal dengan masa mencari jati diri atau disebut dengan identitas ego (ego identity). Hal ini terjadi karena masa remaja merupakan masa peralihan antara masa kehidupan anak-anak dan masa kehidupan orang dewasa. Ditinjau dari fisiknya mereka sudah bukan anak-anak lagi melainkan sudah seperti orang dewasa, tetapi jika diperlakukan seperti orang dewasa, ternyata belum dapat menunjukkan sikap dewasa. Melihat kondisi sekarang apabila di dukung oleh lingkungan yang kurang kondusif dan sifat kepribadian yang kurang baik akan menjadi pemicu timbulnya berbagai penyimpngan perilaku dan perbuatan-perbuatan negative yang melanggar aturan dan norma yang ada di masyarakat yang biasanya disebut dengan kenakalan remaja.

Masa remaja juga merupakan suatu tahapan kehidupan yang bersifat peralihan dan sangat rentan terhadap berbagai masalah karena rawan oleh pengaruh negatif. Namun diakui bahwa masa remaja adalah masa yang amat baik untuk mengembangkan segala potensi yang dimiliki, seperti bakat, kemampuan dan minat. Selain itu juga remaja sebaiknya diberikan bimbingan agama sebagai pedoman hidup karena masa ini adalah masa pencarian nilai-nilai hidup.

Dan salah satu faktor yang mempengaruhi perilaku kenakalan remaja adalah konsep diri yang merupakan pandangan atau keyakinan diri terhadap keseluruhan diri, baik yang menyangkut kelebihan maupun kekurangan diri sehingga mempunyai pengaruh yang besar terhadap keseluruhan perilaku yang ditampilkan. Konsep diri yang dimiliki remaja akan mempengaruhi perilakunya dalam hubungan sosial dengan individu lain. Konsep diri positif akan berpengaruh pada perilaku positif. Sebaliknya konsep diri negatif akan membawa pengaruh yang kurang baik bagi individu.

Kalau dilihat yang dialami generasi sekarang yang terjadi betapa banyak bentuk penyimpangan, yaitu kurangnya moral dan perbuatan yang dapat melanggar normanorma agama yang di hadapi baik oleh anak-anak, ramaja dan dewasa yang 
berdampak pada moral yang dapat membinasakan. Kondisi seperti ini, dalam diri remaja muncul keinginan untuk selalu mencoba sesuatu yang dilihatnya, bertanya tentang dirinya, memilih untuk kepercayaan. Penyimpangan perilaku remaja. ${ }^{1}$ Kondisi seperti ini tanggung jawab bersama, baik orang tua, guru maupun pemertintah. Namun banyak dari sebagian pihak-pihak yang acuh tak acuh terhadap perilaku tersebut dan tidak peduli terhadapnya untuk memberikan solusi alternatif konstruktif dari berbagai masalah yang dihadapi oleh generasi.

Melihat realita kehidupan sekarang ini. Banyaknya terjadi perilaku menyimpang terutama di kalangan remaja mengenai minuman keras yang semakin banyak terjadi baik di pedesaan maupun perkotaan. Maka dari itu peneliti tertarik untuk melakukan penelitian yang berjudul "Konsep Diri Remaja Yang Terlibat Minuman Keras Di Lingkungan Rampusa Kelurahan Betteng Kecamatan Lembang Kabupaten Pinrang”. Alasan penulis mengangkat judul tersebut, karena penulis ingin mengetahui bagaiamana konsep diri remaja yang terlibat dalam minuman keras/khamar dan untuk megetahui penyebab remaja sehingga terjerumus dalam minuman keras/khamar. Kemudian alasan lain mengapa peneliti memilih di Lingkungan Rampusa Kelurahan Betteng Kecamatan Lembang Kabupaten Pinrang sebagai lokasi penelitian karena lokasi tersebut ada disekitar tempat tinggal peneliti.

\section{PEMBAHASAN}

Dalam penulis ini, penulis menggunakan beberapa teori yang relavan sesuai dengan fokus penelitian dari penulis dengan judul "Konsep Diri Remaja Yang Terlibat Dalam Minuman Keras/Khamar Di Lingkungan Rampusa Kelurahan Betteng Kecamatan Lembang Kabupaten Pinrang” sehingga teori yang penulis gunakan antara lain :

\subsubsection{Teori Konsep Diri}

\footnotetext{
${ }^{1}$ Syamsu Yusuf LN., "Psikolagi Perkembangan Anak Remaja” (PT.Remaja Rosda Karya, 2009), h.211
} 
William D.Brooks menedefinisikan konsep diri sebagai "Those Psychical, and Psychlogical perceptions of our selves other". Jadi konsep diri adalah pandangan dan perasaan tentang diri. Persepsi tentang diri ini boleh bersifat psikologi, sosial dan fisik. Konsep ini bukan hanya gambaran deskriptif, tetapi juga penilaian tentang diri. Jadi konsep diri meliputi apa yang dipikirkan dan apa yang dirasakan tentang diri. ${ }^{2}$

Atwater (1987) menyebutkan bahwa konsep diri adalah keseluruhan gambaran diri, yang meliputi persepsi seseorang tentang diri, perasaan, keyakinan, dan nilainilai yang berhubungan dengan dirinya. Selanjutnya, Atwater mengidentifikasi konsep diri atas tiga bentuk. Pertama, bodyimage, kesadaran tentang tubuhnya, yaitu bagaimana seseorang melihat dirinya sendiri. Kedua, ideal self, yaitu bagiamana citacita dan harapan-harapan seseorang mengenai dirinya. Ketiga, socialself, yaitu bagaimana orang lain melihat dirinya. Sementara itu, Cawagas (1983) menjelaskan bahwa konsep diri mencakup seluruh pandangan individu akan dimensi fisiknya, karakteristik pribadinya, motivasinya, kelemahannya, kelebihannya, atau kecakapannya, kegagalannya, dan sebagainya. ${ }^{3}$

Dari pengertian-pengertian diatas dapat disimpulkan bahwa konsep diri adalah pan dangan terhadap diri kita sendiri, mengenai siapa diri kita, apa dan bagaimana diri kita. Pandangan tersebut mulai dari identitas diri, cita diri harga diri, ideal diri gambaran diri serta peran diri kita, yang diperoleh melalui interaksi diri sendiri maupun dengan orang lain.

Konsep diri terbentuk melalui proses belajar sejak masa pertumbuhan seorang manusia dari kecil hingga dewasa. Lingkungan, pengalaman dan pola asuh orang tua turut memberikan pengaruh yang signifikan terhadap konsep diri yang terbentuk. Sikap atau respons orang tua dan lingkungan akan menjadi bahan informasi dari anak untuk menilai siapa dirinya. Oleh sebab itu, seringkali anak-anak yang tumbuh dan di

\footnotetext{
${ }^{2}$ Rahmat. J, psikologi Komunikasi, Remaja Rosdakarya,Bandung,2007,h. 99-100.

${ }^{3}$ Desmita, Psikologi perkembangan peserta didik,(Bandung : PT Remaja Rosdakarya, 2011), h. 163-164.
} 
besarkan dalam pola asuh yang keliru dan negatif, atau lingkungan yang kurang mendukung,cenderung mempunyai konsep diri negatif. Kondisi ini disebabkan sikap orang tua yang misalnya, suka memukul, mengabaikan, kurang memperhatikan,melecehkan, menghina, bersikap tidak adil, tidak pernah memuji, suka marah-marah, memberi hukuman akibat kekurangan, kesalahan ataupun kebodohan, dirinya. Jadi anak menilai dirinya berdasarkan apa yang dia alami dan dapat dapatkan lingkungan. Jika lingkungan memberikan sikap yang baik dan positif,anak akan merasa dirinya cukupberharga sehinggah tumbuhlah konsep diri yang positif. (Haramain, 2012, 2016, 2019; Juddah, 2015; Rahmawati, Wahidin and Aris, 2015; Abdullah, 2016; Hidayat, 2016; Mulianah and Hidayat, 2016; Muliati, 2016; Sunubi, Dalle and Maghdalena, 2016; Anwar, 2016; Azis, Herdah and Jufri, 2016; Budiman, Musyarif and Firman, 2016; Ahdar, 2017; Ilham, 2017; Ipandang, 2017; Al-Amri and Haramain, 2017; Ulum and Haramain, 2017; Azis and Jufri, 2017; Khairul and Haramain, 2018; Muammar and Suhartina, 2018; Tanwir and Said, 2018)(Haramain, 2017; Ulum and Haramain, 2017)

Konsep diri meliputi tidak hanya skema diri kita tentang siapa diri kita saat ini, namun juga tentang akan menjadi apa diri kita nantinya yaitu kemungkinan diri (possible selves) kita. Markus \& Nurius menyatakan bahwa kemungkinan diri kita meliputi visi-visi kita mengenai diri kita yang kita impikan, seperti diri yang kaya, kurus, dicintai dan mencintai. Juga meliputi diri yang kita takutkan seperti diri yang pengangguran, tidak dicintai, gagal secara akademis. Kemungkinan diri yang seperti memotivasi kita dengan sebuah visi tentang kehidupan yang kita inginkan. ${ }^{4}$

\subsubsection{Konsep Diri Positif}

Menurut Brooks dan Emmart (1976), orang yang memiliki konsep diri positif menunjukkan karakteristik sebagai berikut :

\footnotetext{
${ }^{4}$ David G Mayer, Psikologi Sosial,(jakarta : Salemba Humanika,2012),h.48
} 
1. Merasa mampu mengatasi masalah. Pemahaman diri tehadap kemampuan subjektif untuk mengatasi persoalan-persoalan objektif yang di hadapi.

2. Merasa setara dengan orang lain. Pemahaman bahwa manusia dilahirkan tidak dengan membawa pengetahuan dan kakayaan. Pengetahuan dan kekayaan didapatkan dari proses belajar sepanjang hidup. Pemahaman tersebut menyebabkan individu tidak merasa lebih atau kurang dibandingkan dengan orang lain.

3. Menerima pujian tanpa rasa malu. Pemahaman terhadap pujian, atau penghargaan layak diberikan terhadap individu berdasarkan dari hasil apa yang telah dikerjakan sebelumnya.

4. Merasa mampu memperbaiki diri kemampuan untuk melakukan proses refleksi diri untuk memperbaiki perilaku yang dianggap kurang.

\subsubsection{Konsep Diri Negatif}

1. Peka terhadap kritik. Kurangnya kemampuan untuk menerima kritik dari orang lain sebagai proses refleksi diri.

2. Bersikap responsif terhadap pujian. Bersikap berlebihan terhadap tindakan yang telah dilakukan, sehingga merasa segala tindakannya perlu mendapat penghargaan.

3. Cenderung merasa tidak disukai orang lain. Perasaan subjektif bahwa setiap orang disekitarnya memandang dirinya negatif.

4. Mempunyai sikap hiperkritik. Suka melakukan kritik negatif secara berlebihan terhadap orang lain.

5. Mengalami hambatan dalam interaksi dengan lingkungan sosialnya. Merasa kurang mampu dalam berinteraksi dengan orang-orang lain disekitarnya. ${ }^{5}$

2.2.1.3 beberapa unsur konsep diri antara lain

1. Penilaian diri merupakan pandangan diri

${ }^{5}$ Edi Harapan, Syarwani Ahmad, Komunikasi Antarpribadi, ( Jakarta : PT Rajagrafindo Persada, 2014), h. 90-91 
2. Pengendalian keyakinan dan dorongan dalam diri bagaimana kita mengetahui dan mengendalikan dorongan, kebutuhan dan perasaan-perasaan dalam diri.

3. Suasana hati yang sedang kita hayati seperti bahagia, sedih atau cemas. Keadaan ini akan memengaruhi konsep diri kita positif atau negatif.

4. Bayangan subjektif terhadap kondisi tubuh kita. Konsep diri yang positif aakan dimiliki kalau merasa puas (menerima) keadaan fisik diri sendiri. Sebaliknya, kalau merasa tidak puas dan menilai buruk keadaan fisik sendiri maka konsep diri juga negatif atau akan jadi memiliki perasaan rendah diri.

5. Penilaian sosial merupakan evaluasi terhadap bagaiamana individu menerima penilaian lingkungan sosial pada dirinya. Penilaian sosial terhadap diri yang cerdas, supel akan mampu meningkatkan konsep diri dan kepercayaan diri. Adapun pandangan lingkungan pada individu seperti si gendut, si bodoh, atau si nakal akan menyebabkan individu memiliki konsep diri yang negatif terhadap dirinya.

Konsep diri yang terbentuk pada diri juga akan menentukan penghargaan yang di berikan pada diri. Penghargaan terhadap diri atau yang lebih dikenal dengan self esteem ini meliputi penghargaan terhadap diri sebagai manusia yang memiliki tempat di lingkungan sosial. Penghargaan ini akan memengaruhi dalam berinteraksi dengan orang lain. ${ }^{6}$

\section{REFERENCES}

(1) Abdullah, B. (2016) 'KONSTITUSI PENDIDIKAN ISLAM DALAM MEMBANGUN MASYARAKAT MADANI', KURIOSITAS: Media Komunikasi Sosial Keagamaan, 9(2), pp. 79-86.

(2) Ahdar, A. (2017) 'TINJAUAN KRITIS DAN MENYELURUH TERHADAP FUNDAMENTALISME DAN RADIKALISME ISLAM MASA KINI',

\footnotetext{
${ }^{6}$ Nina w. Syam. Psikologi Sosial Sebagai Akar Ilmu Komunikasi, (Bandung : Simbiosa Rekatama Media,2014), h . 56-58
} 
KURIOSITAS: Media Komunikasi Sosial dan Keagamaan, 10(1), pp. 19-36.

(3) Al-Amri, L. and Haramain, M. (2017) 'AKULTURASI ISLAM DALAM BUDAYA LOKAL', KURIOSITAS, 10(2), pp. 87-100.

(4) Anwar, A. (2016) 'KONTRIBUSI KELUARGA TERHADAP PEMBENTUKAN KARAKTER ANAK (Studi Perspektif Modal Sosial di Kota Parepare)', KURIOSITAS, 9(1), pp. 57-65.

(5) Azis, A. and Jufri, M. (2017) 'IMPLEMENTASI NILAI-NILAI AJARAN TAU LOTANG TERHADAP MASYARAKAT LOKAL WATTANG BACUKIKI KOTA PAREPARE', KURIOSITAS: Media Komunikasi Sosial dan Keagamaan, 10(2), pp. 23-41.

(6) Azis, S. A., Herdah, H. and Jufri, M. (2016) 'IMPLEMENTASI MODEL PEMBELAJARAN KOOPERATIF MAHASISWA PROGRAM STUDI BAHASA ARAB STAIN PAREPARE (Studi Pengembangan Pembelajaran Mata Kuliah Serumpun)', KURIOSITAS, 9(1), pp. 81-102.

(7) Budiman, B., Musyarif, M. and Firman, F. (2016) 'IDEOLOGI BULETIN DAKWAH AL-ISLAM DALAM KAJIAN WACANA KRITIS', KURIOSITAS, 9(1), pp. 21-34.

(8) Haramain, M. (2012) 'Pemikiran dan Gerakan Dakwah Tuan Guru M. Zainuddin Abdul Madjid di Lombok NTB'. Makassar: Universitas Islam Negeri Alauddin Makassar.

(9) Haramain, M. (2016) 'al-Wasathiyyah wa Atsaruha fi al-da'wah alIslamiyyah: Dirasah Lugawiyyah Manhajiyyah', Langkawi: Journal of The Association for Arabic and English, 2(1), pp. 83-100.

(10) Haramain, M. (2017) 'DAKWAH DALAM ARUS GLOBALISASI MEDIA: PELUANG DAN TANTANGAN', KOMUNIDA: MEDIA KOMUNIKASI DAN DAKWAH, 7(1), pp. 60-73.

(11) Haramain, M. (2019) Prinsip-prinsip Komunikasi dalam al-Qur'an. Parepare: IAIN Parepare Nusantara Press.

(12) Hidayat, W. (2016) 'PERSEPSI SISWA SMA KOTA PAREPARE 
TENTANG STAIN PAREPARE', KURIOSITAS: Media Komunikasi Sosial Keagamaan, 9(1), pp. 49-56.

(13) Ilham, M. I. M. (2017) 'HERMENEUTIKA AL-QUR'AN', KURIOSITAS: Media Komunikasi Sosial dan Keagamaan, 10(2), pp. 101-119.

(14) Ipandang, I. (2017) 'FILSAFAT AKHLAK DALAM KONTEKS PEMIKIRAN ETIKA MODERN DAN MISTISISME ISLAM SERTA KEMANUSIAAN', KURIOSITAS: Media Komunikasi Sosial dan Keagamaan, 10(1), pp. 1-18.

(15) Juddah, A. B. (2015) 'ANALITIS SINTETIK TERHADAP STRATEGI PEMBELAJARAN ANDRAGOGI BERPERSPEKTIF KEMANDIRIAN DOSEN DALAM PEMBELAJARAN', Kuriositas: Media Komunikasi Sosial dan Keagamaan, 8(2), pp. 41-45.

(16) Khairul, K. and Haramain, M. (2018) 'Aplikasi Digital Risalah Ilmu Tajwid dalam Meningkatkan Kemampuan Baca Al Qur'an', KURIOSITAS: Media Komunikasi Sosial dan Keagamaan, 11(2), pp. 145-157.

(17) Muammar, M. and Suhartina, S. (2018) 'Media Pembelajaran Berbasis Teknologi Informasi Dalam Meningkatkan Minat Belajar Akidah Akhlak', KURIOSITAS: Media Komunikasi Sosial dan Keagamaan, 11(2), pp. 176188.

(18) Mulianah, S. and Hidayat, W. (2016) 'PENGEMBANGAN TES BERBASIS KOMPUTER', KURIOSITAS: Media Komunikasi Sosial dan Keagamaan, $9(2)$, pp. 27-43.

(19) Muliati, M. (2016) 'PENGARUH PAHAM KEAGAMAAN TERHADAP ETOS KERJA PEDAGANG PASAR SENTRAL KABUPATEN PINRANG', KURIOSITAS: Media Komunikasi Sosial Keagamaan, 9(2), pp. 101-115.

(20) Rahmawati, R., Wahidin, W. and Aris, A. (2015) 'MATERI FIQH IBADAH DAN IMPLEMENTASINYA BAGI MAHASISWA JURUSAN SYARIAH STAIN PAREPARE', KURIOSITAS: Media Komunikasi Sosial Keagamaan, 8(1), pp. 71-86. 
(21) Sunubi, A. H., Dalle, A. and Maghdalena, M. (2016) 'ENGLISH TEACHER INSTRUCTION IN GIVING MATERIAL BY USING CODE SWITCHING AND CODE MIXING IN SMU NEG. 2 PAREPARE', KURIOSITAS, 9(1), pp. 35-47.

(22) Tanwir, T. and Said, H. (2018) 'Inovasi Pembelajaran Guru Pendidikan Agama Islam Berbasis Teknologi Informasi', KURIOSITAS: Media Komunikasi Sosial dan Keagamaan, 11(2), pp. 189-210.

(23) Ulum, A. C. and Haramain, M. (2017) 'EKSISTENSI DAKWAH DALAM MERESPON PLURALISME', KOMUNIDA: MEDIA KOMUNIKASI DAN DAKWAH, 7(2), pp. 124-138. 